\title{
АНАЛИЗ РЕАКЦИИ ФРУСТРАЦИИ У ДЕТЕЙ И ПОДРОСТКОВ НА ФОНЕ ОЖИРЕНИЯ
}

\section{Компаниец О.В., Болотова Н.В., Филина Н.Ю., Рассказова Ю.В.}

\author{
ФГБОУ ВО Саратовский ГМУ им. В.И. Разумовского Минздрава России, Саратов, Россия
}

Актуальность. Высокая распространенность ожирения в мире подразумевает постоянный поиск возможных медикаментозных и немедикаментозных способов снижения массы тела. В детской популяции ввиду ограничения разрешенных медикаментозных способов коррекции на первый план выходит терапевтическое обучение детей и родителей, напрвленное на изменение пищевого поведения.

Цель работы: изучение реакции фрустрации у пациентов с ожирением как одного из возможных факторов, препятствующих изменению пищевого поведения.

Материалы и методы. Основную группу составили пациенты с ожирением от 7 до 17 лет $(\mathrm{n}=52)$, из них мальчиков - 20 чел. (39\%), девочек - 32 чел. (61\%). В качестве контрольных данных были взяты результаты тестирования здоровых детей такого же возраста, опубликованных в работах Е.Е.Даниловой и С.Розенцвейга. Метод исследования - тест фрустрационных реакций С.Розенцвейга, представляющий собой комплект из 24 иллюстраций, отражающих различные жизненные, потенциально фрустрирующие (психотравмирующие), ситуации. Процедура тестирования независимо от возраста составляла в среднем 10-12 минут.

Результаты исследования. С учётом степени тяжести ожирения пациенты были разделены на 3 группы: 1-я степень (SDS ИМТ =2,1-2,5) - 23 чел. (44\%), 2-я (SDS ИМТ =2,6-3,0) - 9 чел. (17\%), 3-я (SDS ИMT =3,1-3,9) - 20 чел. (39\%). Наследственная отягощенность по ожирению была выявлена у 23 чел. (44\%) из общего числа тестируемых. Сниженный критерий GCR как показатель степени социальной адаптации был получен у 35 чел. $(66,6 \%)$. У большинства пациентов (56\%) были выявлены импунитивные реакции фрустрации, что отражает позицию уклонения от психотравмирующей ситуации, причем с увеличением возраста доля таких реакций возрастает (40\% - у младших школьников, 75\% - у подростков). Анализируя типы реакций фрустрации, было получено преобладание препятственно-доминантного и эго-защитного типов, что указывает на нежелание испытуемых совершать какие-либо необходимые исправления. Вместе с тем, у пациентов с 1-ой и 3ей степенями ожирения преобладали импунитивные реакции препятственно-доминантного типа, со 2ой степенью (преимущественно у девочек) - экстрапунитивные реакции потребностно-настойчивого типа. Вероятно, что пациенты 1-й группы (с ожирением 1-й степени) не воспринимают ожирение как болезнь или проблемную ситуацию, требующую разрешения; пациенты с ожирением 3-й степени занимают пассивную позицию по отношению к своему состоянию по причине неразрешимости, на их взгляд, ситуации.

Выводы. Большинство пациентов с ожирением проявляют импунитивные реакции фрустрации, что указывает на позицию уклонения, дистанцирования от разрешения психотравмирующей ситуации. Пациенты со 2-й степенью ожирения, преимущественно девочкиподростки, имеющие экстрапунитивные реакции потребностно-настойчивого типа, представляют собой наиболее перспективных потенциальных участников программ снижения массы тела ввиду готовности к коррекции пищевого поведения. Анализ реакции фрустрации у пациентов с ожирением с целью выявления наиболее приверженных терапии пациентов может способствовать повышению эффективности работы школ терапевтического обучения. 